\title{
Raman spectroscopic identification of cookeite in the crystal-rich inclusions in spodumene from the Jiajika lithium pegmatite deposit, China, and its geological implications
}

\author{
Xin Ding ${ }^{1}$, Jiankang $\mathrm{Li}^{2}$, I-Ming $\mathrm{Chou}^{3}$, Zhenyu Chen ${ }^{2}$, and Shenghu $\mathrm{Li}^{4}$ \\ ${ }^{1}$ State Key Laboratory of Geological Processes and Mineral Resources, \\ China University of Geosciences (Beijing), Beijing 100083, China \\ ${ }^{2}$ MNR Key Laboratory of Metallogeny and Mineral Assessment, Institute of Mineral Resources, \\ Chinese Academy of Geological Sciences, Beijing 100037, China \\ ${ }^{3}$ CAS Key Laboratory of Experimental Study Under Deep-sea Extreme Conditions, Institute of Deep-sea \\ Science and Engineering, Chinese Academy of Sciences, Sanya 572000, China \\ ${ }^{4}$ Shandong Institute of Geological Sciences, Ji'nan 250013, China
}

Correspondence: Jiankang Li (li9968@126.com)

Received: 1 January 2019 - Accepted: 18 September 2019 - Published: 16 January 2020

\begin{abstract}
Cookeite usually occurs as a late alteration product in lithium-cesium-tantalum-type granitic pegmatite. Consequently, cookeite-bearing crystal-rich inclusions (CIs) in pegmatite are considered to be of secondary origin, which constrains our understanding of pegmatite formation. Thus far, no reported cookeite has produced a distinct Raman spectrum. However, the CIs hosted in spodumene in the Jiajika pegmatite deposit, China, contain a cookeite-like hydrous lithium-aluminum-silicate phase, yielding a distinct Raman spectrum. In electron microprobe analysis, focused ion beam scanning electron microscopy, and time-of-flight secondary ion mass spectrometry (ToF-SIMS), the average composition of this hydrous phase was determined as $\mathrm{Li}_{1.005}\left(\mathrm{Al}_{3.997} \mathrm{Fe}_{0.018}\right)\left(\mathrm{Si}_{3.086} \mathrm{Al}_{0.914}\right) \mathrm{O}_{10.076} \mathrm{OH}_{7.902} \mathrm{~F}_{0.098}$, close to the International Mineralogical Association (IMA) formula of cookeite, $(\mathrm{Al}, \mathrm{Li})_{3} \mathrm{Al}_{2}(\mathrm{Si}, \mathrm{Al})_{4} \mathrm{O}_{10}(\mathrm{OH})_{8}$. The distinct Raman peaks at 98, 167, 219, 266, 342, $382,457,592,710$, and $3640 \mathrm{~cm}^{-1}$ were consistent with those of natural cookeite recrystallized in a hydrothermal diamond-anvil cell. The peaks were ascribed to the crystallization of cookeite from the liquid trapped in the closed space during the spodumene crystallization, which occurred at relatively high temperature and pressure without incorporating the minor elements commonly present during alteration processes. These minor elements often obscure the Raman signals, primarily by fluorescence effects. This type of cookeite in CIs with distinct Raman signals is unusual and can indicate whether the cookeite crystallized from fluid trapped within the closed space of a primary inclusion. In such a case, the fluid can be considered a flux-rich hydrous melt in pegmatite formation models.
\end{abstract}

\section{Introduction}

Cookeite is an uncommon member of the chlorite group, with the IMA formula $\mathrm{LiAl}_{4}\left(\mathrm{Si}_{3} \mathrm{Al}\right) \mathrm{O}_{10}(\mathrm{OH})_{8}$ (Anthony et al., 1995). Most cookeite is a late hydrothermal alteration product of spodumene, petalite, and other Li-rich minerals, which form in granite pegmatites at low temperatures (Černý,
1970; Heinrich, 1975; London and Burt, 1982; Bobos et al., 2007; Novák et al., 2015). Cookeite is occasionally found in hydrothermal veins or hydrothermally altered sedimentary rocks (Vidal and Goffé, 1991). It also occurs in crystalrich inclusions (CIs), which characterize the fluid inclusions in granitic pegmatites (Roedder, 1992). Because cookeite is conventionally thought to have formed in the late-stage al- 
teration processes, its presence in CIs implies a secondary origin of the CIs (Anderson et al., 2001; Anderson and Maccarron, 2011; Anderson, 2013). Despite its common occurrence, no natural cookeite, including CI-enclosed cookeites in pegmatite environments, is known to produce distinct Raman signals. Consequently, no characteristic Raman spectrum of cookeite has been reported. In the database of Raman spectra, X-ray diffraction, and chemical data (RRUFF), the Raman spectra of cookeite are very noisy, with no distinct peaks (Downs, 2006). Therefore, cookeite has been identified mainly by analyzing its composition or by semiquantitative X-ray spectroscopy (London, 1986; Anderson and Maccarron, 2011).

However, the Jiajika pegmatite-type lithium deposit in western Sichuan, China, contains a cookeite-like hydrous solid phase within spodumene-hosted CIs, which yields a distinct Raman spectrum (Fig. 5 in Li and Chou, 2016). In the present study, this hydrous solid phase is confirmed as being cookeite by further analyses, including with an electron microprobe (EMP), focused ion beam scanning electron microscope (FIB-SEM), and time-of-flight secondary ion mass spectrometer (ToF-SIMS); its Raman signals are compared with those of a natural cookeite recrystallized in a hydrothermal diamond-anvil cell (HDAC). Given the unusual Raman feature of the cookeite in the CIs from the Jiajika pegmatite, we infer an origin different from those of secondary CIs (Anderson et al., 2001; Anderson and Maccarron, 2011; Anderson, 2013). The cookeite might have formed from fluid originally trapped during the crystallization of spodumene. Therefore, this fluid can be considered to be a primary flux-rich hydrous melt in pegmatite formation models (London, 1999, 2008, 2018; Thomas et al., 2000, 2009, 2011a, b). In this paper, we suggest that cookeite in CIs with distinct Raman signals is a viable indicator of the primary nature of CIs in pegmatite.

\section{Features of cookeite-like phases within the crystal-rich inclusions in the Jiajika pegmatite deposit}

The Jiajika granitic pegmatite in western Sichuan, China, is the largest lithium deposit in Asia (Li et al., 2013a). In this deposit, the pegmatite dikes radiate horizontally and vertically around the two-mica granite intrusion. With increasing distance from the granite, the mineralogy of pegmatite dikes change from microcline pegmatite, to microcline-albite pegmatite, albite pegmatite, spodumene pegmatite, and lepidolite (muscovite) pegmatite. The two-mica granite and pegmatites are hosted in schists formed by metamorphic overprint of early Triassic mudstones and sandstones $(\mathrm{Li}$ et al., 2007). The spodumene pegmatite dikes are the main lithium ore bodies; they are mainly composed of spodumene, quartz, albite, muscovite, and a few rare metal minerals of columbite, beryl, tantalite, thorite, and sicklerite ( $(\mathrm{Li}$,

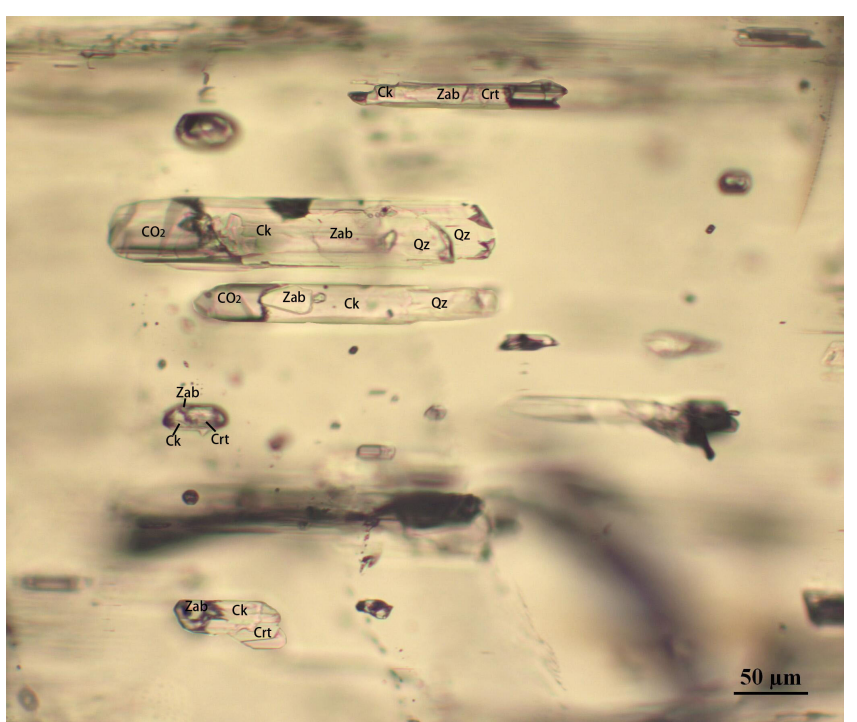

Figure 1. Photomicrographs of spodumene-hosted crystal-rich inclusions (CIs) in the Jiajika deposit, showing one fluid inclusion assembly (FIA) of CIs with a uniform composition and the crystal/fluid proportion. Crt - cristobalite; Spd - spodumene; Zab zabuyelite; Cal - calcite, Qz - quartz; Ck - cookeite.

$\mathrm{Mn}) \mathrm{PO}_{4}$ ). The spodumene crystals are white or off-white euhedral plates $5-10 \mathrm{~cm}$ in length and $1-5 \mathrm{~cm}$ in width and are clearly in contact with quartz and albite crystals ( $\mathrm{Li}$ and Chou, 2016). The late alteration is relatively weak in the spodumene pegmatite, and occasionally spodumene was replaced by albite in myrmekitic texture at the contact face with microcline. Currently, cookeite crystals, formed through late hydrothermal alteration of spodumene at low temperature, were not observed in the pegmatite dikes.

In the spodumene pegmatite in the Jiajika deposit, the CIs of the spodumene often contain a hydrous solid phase that has been identified and imaged with Raman spectroscopy (Figs. 1, 2; Li and Chou, 2016). Electron microprobe (EMP) analyses suggest a cookeite composition of this phase ( $\mathrm{Li}$ and Chou, 2016). The CIs, which often occur as isolated individuals or in-fluid inclusion assemblages (FIAs) with similar composition and crystal/fluid proportion, are considered to be primary in origin (Fig. 1). The exceptions are FIAs of CIs that are cross-cut by late stage $\mathrm{CO}_{2}-\mathrm{H}_{2} \mathrm{O}-\mathrm{NaCl}$ and aqueous fluid inclusions ( $\mathrm{Li}$ and Chou, 2016, 2017). The primary CIs are $20-100 \mu \mathrm{m}$ long and $10-20 \mu \mathrm{m}$ wide and have a subhedral to euhedral negative spodumene crystal shape. Within the CIs, the cookeite-like phase is commonly accompanied by semi-euhedral crystals of zabuyelite, cristobalite, and quartz (Fig. 2; $\mathrm{Li}$ and Chou, 2016). It coexists with a $\mathrm{CO}_{2}$ phase, and occasionally coexists with an aqueous phase (Figs. 1 and 2). In CI heating experiments, the cookeite-like phase, zabuyelite, cristobalite, and quartz dissolve and melt at 400$600{ }^{\circ} \mathrm{C}$, and the CIs are homogenized into a carbonate-rich aqueous fluid at $500-700^{\circ} \mathrm{C}$ ( $\mathrm{Li}$ and $\left.\mathrm{Chou}, 2017\right)$. 

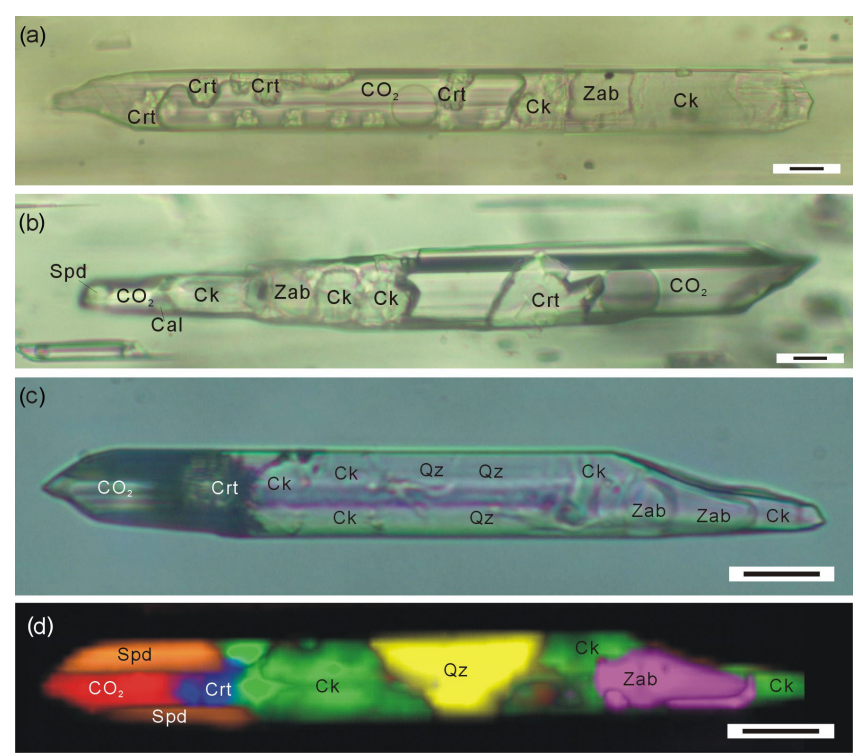

Figure 2. Crystal-rich inclusions (CIs) hosted in spodumene from the Jiajika deposit. Crt - cristobalite, Spd - spodumene, Zab zabuyelite; Cal - calcite, Qz - quartz; Ck - cookeite. (d) Raman map of the CI shown in (c). The length of the scale bar is $10 \mu \mathrm{m}$.

\section{Analytical methods of cookeite}

The hydrous solid phase within the spodumene-hosted CIs was analyzed by Raman spectroscopy (Horiba LabRam HR800 Raman spectrometer, Horiba Trading Co., Ltd., Beijing Branch, China). To minimize fluorescence, the excitation beam wavelength was set to $633 \mathrm{~nm}$. The power on the sample surface was $4.1 \mathrm{~mW}$. The spectrometer was calibrated with silica to an accuracy of $\pm 0.2 \mathrm{~cm}^{-1}$. Two accumulations of the unpolarized spectrum were collected for $120 \mathrm{~s}$ for each spectral window through a $100 \times$ Olympus objective lens (NA $=0.90)$. Under these conditions, one CI containing the hydrous solid phase was mapped to an $x-y$ resolution of $1 \mu \mathrm{m}$, with a spectrum-collecting time of $10 \mathrm{~s}$ per spot (Fig. 2d).

After polishing the sample wafer until the hydrous solid phase in the CIs was exposed to air, the sample was analyzed using a JXA-8230 EMP at the Institute of Mineral Resources, Chinese Academy of Geological Sciences, in wavelengthdispersive mode. Operating conditions for analyses were as follows: an accelerating voltage of $15 \mathrm{kV}$, a beam current of $10 \mathrm{nA}$, and a beam diameter of $10 \mu \mathrm{m}$ was used for cookeite. The following standards and X-ray lines were used, $K \alpha$ lines: $\mathrm{Si}, \mathrm{Na}$ - Jadeite; $\mathrm{Al}$ - kyanite, $\mathrm{Ca}$ - wollastonite; $\mathrm{K}$, $\mathrm{F}$ - phengite; $\mathrm{Cr}_{-} \mathrm{Cr}_{2} \mathrm{O}_{3} ; \mathrm{Mg}$ - olivine; $\mathrm{Fe}$ - hematite; $\mathrm{Mn}$ spessartine; and $\mathrm{Ti}$ - rutile. The raw data were reduced using the ZAF correction procedure.

The composition of the exposed hydrous solid phase was then analyzed by a FIB-SEM combined with ToF-SIMS based on a gallium ion source. The ToF-SIMS analyzer was mounted on a TESCAN LYRA instrument platform (TOFWERK AG, CNNC Beijing Research Institute of Uranium Geology). In this analysis, the ion beam energy and current were set to $15 \mathrm{keV}$ and $200 \mathrm{pA}$, respectively. The staying time and milling depth on the crystal surface were $10 \mu$ s and $\sim 0.2 \mu \mathrm{m}$, respectively, over an area of approximately $(10 \times 10) \mu \mathrm{m}^{2}$.

To prove that the hydrous solid phase in CIs is indeed cookeite, we recrystallized a natural cookeite sample from Minas Gerais pegmatite, Brazil (Catalogue No. 115846 00, National Museum of Natural History, Smithsonian Institution, USA), in a hydrothermal diamond-anvil cell (HDAC, type HDAC-VT; Li et al., 2016). The cookeite sample contained $46.63 \mathrm{wt} \% \quad \mathrm{Al}_{2} \mathrm{O}_{3}, 35.77 \mathrm{wt} \% \mathrm{SiO}_{2}, 0.62 \mathrm{wt} \% \mathrm{~F}$, $0.24 \mathrm{wt} \% \mathrm{MnO}, 0.09 \mathrm{wt} \% \mathrm{SnO}, 0.08 \mathrm{wt} \% \mathrm{SrO}, 0.03 \mathrm{wt} \%$ $\mathrm{Cs}_{2} \mathrm{O}, 0.03$ wt \% $\mathrm{Pb}, 0.02$ wt $\% \mathrm{~K}_{2} \mathrm{O}, 0.01$ wt $\% \mathrm{Cl}$, which were analyzed with EMP at the conditions described above. Following Li et al. (2013b), the preheated cookeite sample and pure water were sealed together with an air bubble in the HDAC sample chamber. The sample chamber is a hole (of diameter $0.5 \mathrm{~mm}$ ) at the center of a Re gasket (of diameter and thickness 3.0 and $0.125 \mathrm{~mm}$, respectively), sealed by compressing the gasket with two parallel diamond-anvil faces $(1.0 \mathrm{~mm}$ diameter). During heating, the sample temperatures were controlled and measured by a temperature controller (PES 1300, PES Enterprise Inc., USA). After carefully determining the temperature at which the vapor bubble disappeared $\left(T_{\mathrm{hDC}}\right)$, the sample was heated at $5^{\circ} \mathrm{C} \mathrm{min}^{-1}$ until the cookeite began to dissolve and melt. The heating rate was then reduced by $1{ }^{\circ} \mathrm{Cmin}^{-1}$ until approximately $40 \mathrm{vol} \%$ of the cookeite had dissolved and melted. Subsequently, the sample chamber was cooled at $1^{\circ} \mathrm{C} \mathrm{min}^{-1}$ to approximately $200^{\circ} \mathrm{C}$, when the cookeite recrystallized around the remaining cookeite residue. During the heating and cooling processes, the pressures within the HDAC chamber were calculated from the bulk $\mathrm{H}_{2} \mathrm{O}$ densities obtained at $T_{\mathrm{hDC}}$ using the equation of state of $\mathrm{H}_{2} \mathrm{O}$ (Wagner and Pruss, 2002). Finally, the recrystallized cookeite was removed from the HDAC chamber and analyzed by using a JY Horiba LabRam HR800 Raman spectrometer with the spectrum-collecting time of $120 \mathrm{~s}$ with two accumulations.

\section{Analytical results}

As shown in Figs. $3 \mathrm{~b}$ and 4 (see also Fig. 5 of $\mathrm{Li}$ and Chou, 2016), the Raman spectra of the hydrous solid phase in the CIs show clear and distinct peaks at 98, 167, 219, 266, and $3640 \mathrm{~cm}^{-1}$. The Raman spectrum of the cookeite recrystallized in the HDAC chamber exhibited the same peaks, along with less-evident peaks near 342, 382, 457, 592, and $710 \mathrm{~cm}^{-1}$ (Fig. 3c), without the noise of natural cookeite as shown in Fig. 3d. This spectrum is not obscured by the strong Raman peaks of spodumene that hosts the CIs (Fig. 3a). Therefore, the Raman signal of the hydrous solid phase in CIs was distinct and matched that of recrystallized cookeite. 


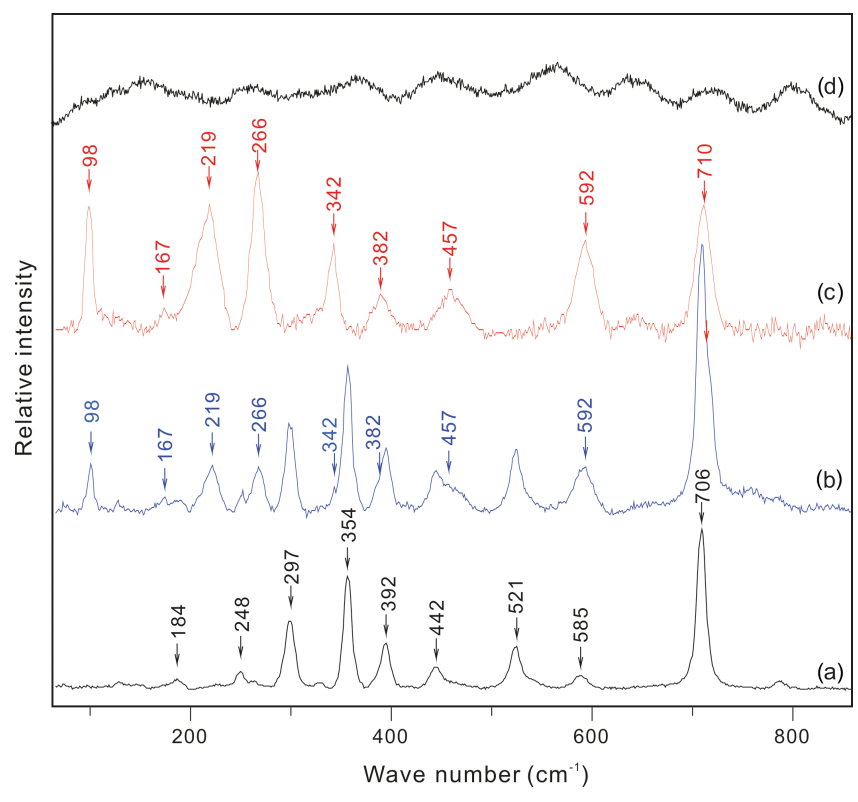

Figure 3. Raman spectra of (a) inclusion-free spodumene, (b) a hydrous solid phase in the spodumene-hosting crystal-rich inclusions, and (c) recrystallized cookeite in the HDAC sample chamber. (d) Natural cookeite before crystallization experiments from the Minas Gerais pegmatite, Brazil, which bears high fluorescence even when collected for $1 \mathrm{~s}$ with an excitation beam of $633 \mathrm{~nm}$ wavelength through a $100 \times$ Olympus objective lens $(\mathrm{NA}=0.90)$. The characteristic Raman peaks are marked.

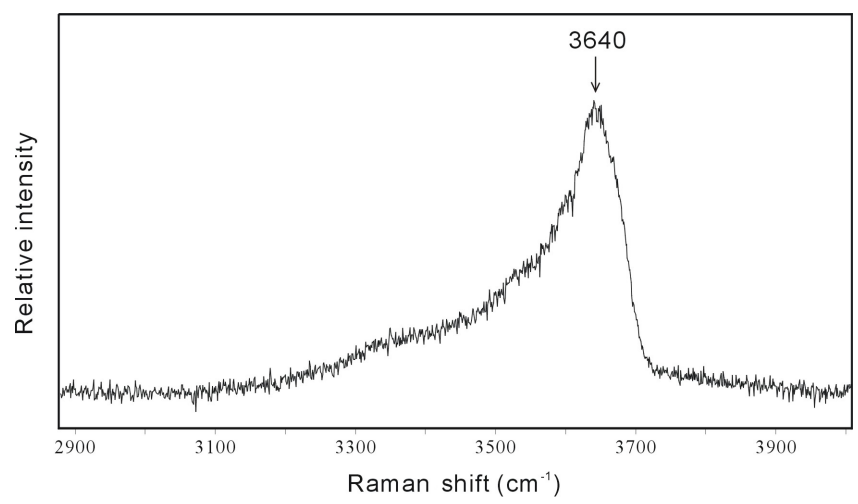

Figure 4. Raman spectrum of the hydrous solid phase cookeite in a spodumene-hosted crystal-rich inclusion in the high wave number region, showing the characteristic peak near $3640 \mathrm{~cm}^{-1}$ in a hydrous sample.

The average compositions of four hydrous solid crystals in the CIs, determined in the EMP analysis, were $47.96 \mathrm{wt} \%$ $\mathrm{Al}_{2} \mathrm{O}_{3}, 35.51 \mathrm{wt} \% \mathrm{SiO}_{2}$, and $15.90 \mathrm{wt} \%$ undetermined mass (Table 1). In SEM observations, the hydrous solid phase is in direct contact with the spodumene host, with no evidence of reaction or intergrowth with spodumene or other minerals. These findings are consistent with the Raman mapping result (Fig. 2d). In one CI with perfect crystal shape of spodumene,
Table 1. Compositions of representative hydrous solid phases in the CIs from the Jiajika pegmatite analyzed by EMP and calculated using the chemical formula of cookeite.

\begin{tabular}{|c|c|c|c|c|c|}
\hline & \multicolumn{4}{|c|}{ Numbers of analyzed samples } & \multirow{2}{*}{$\begin{array}{r}\text { Average } \\
\text { value }\end{array}$} \\
\hline & JPC-1 & JPC-2 & JPC-3 & JPC-4 & \\
\hline \multicolumn{6}{|c|}{ Composition (wt \%) } \\
\hline & JPC-1 & JPC-2 & JPC-3 & JPC-4 & Average \\
\hline $\mathrm{SiO}_{2}$ & 34.45 & 35.36 & 35.96 & 36.27 & 35.51 \\
\hline $\mathrm{Al}_{2} \mathrm{O}_{3}$ & 49.01 & 48.20 & 47.31 & 47.31 & 47.96 \\
\hline $\mathrm{Fe}_{2} \mathrm{O}_{3}$ & 0.34 & 0.27 & 0.26 & 0.24 & 0.28 \\
\hline $\mathrm{F}$ & 0.36 & 0.21 & 0.37 & 0.49 & 0.36 \\
\hline $\mathrm{H}_{2} \mathrm{O}^{*}$ & 13.01 & 13.18 & 13.00 & 12.93 & 13.03 \\
\hline $\mathrm{Li}_{2} \mathrm{O}$ & 2.84 & 2.78 & 3.12 & 2.76 & 2.87 \\
\hline $\mathrm{O}=\mathrm{F}, \mathrm{Cl}$ & 0.15 & 0.09 & 0.15 & 0.21 & 0.15 \\
\hline Total & 99.85 & 99.91 & 99.85 & 99.79 & 99.85 \\
\hline \multicolumn{6}{|l|}{ APFU } \\
\hline $\mathrm{Si}^{4+}$ & 2.998 & 3.067 & 3.123 & 3.154 & 3.086 \\
\hline $\mathrm{Al}^{\mathrm{iv}}$ & 1.002 & 0.933 & 0.877 & 0.846 & 0.914 \\
\hline $\mathrm{Al}^{\mathrm{vi}}$ & 4.026 & 3.994 & 3.966 & 4.004 & 3.997 \\
\hline $\mathrm{Fe}^{3+}$ & 0.022 & 0.018 & 0.017 & 0.016 & 0.018 \\
\hline $\mathrm{Li}^{+}$ & 0.994 & 0.970 & 1.090 & 0.965 & 1.005 \\
\hline $\mathrm{OH}^{-}$ & 7.901 & 7.942 & 7.898 & 7.865 & 7.902 \\
\hline F & 0.099 & 0.058 & 0.102 & 0.135 & 0.098 \\
\hline Total & 17.977 & 17.983 & 17.987 & 17.965 & 17.978 \\
\hline
\end{tabular}

When calculating the contents of $\mathrm{Li}_{2} \mathrm{O}, \mathrm{H}_{2} \mathrm{O}$, and the atoms per formula unit (APFU) in the hydrous solid phase (cookeite), we assumed that cookeite (chemical formula $\left.\mathrm{LiAl}_{4}\left(\mathrm{Si}_{3} \mathrm{Al}\right) \mathrm{O}_{10}(\mathrm{OH})_{8}\right)$ contains 18 oxygen atoms and $(\mathrm{OH}+\mathrm{F}+\mathrm{Cl})=8$ per unit cell. $\mathrm{H}_{2} \mathrm{O}^{*}$ was calculated assuming $(\mathrm{OH}+\mathrm{F}+\mathrm{Cl})=8 \mathrm{APFU}$. All Fe in the solid phase was considered $\mathrm{Fe}^{3+}$.

cookeite-like phases, together with bipyramidal quartz, were strictly confined within the CI (Fig. 5a). The crystals in the SEM images taken at the ion beam energy of $5 \mathrm{keV}$ appeared as $0.2-2.0 \mu \mathrm{m}$ scales or as spherulites with diameters of $0.1-$ $0.2 \mu \mathrm{m}$ (Fig. 5b). The ToF-SIMS analysis confirmed that besides silica and aluminum, the crystals contain rather high contents of lithium (Fig. S1 in the Supplement).

In the dissolution and melting experiment of cookeite, the vapor-bubble-disappearing temperature $\left(T_{\mathrm{hDC}}\right)$ within the HDAC chamber was $316^{\circ} \mathrm{C}$, indicating an $\mathrm{H}_{2} \mathrm{O}$ bulk density of $0.67681 \mathrm{~g} \mathrm{~cm}^{-3}$ in the chamber (Wagner and Pruss, 2002). Obvious dissolution and melting of the natural cookeite began at approximately $520^{\circ} \mathrm{C}$ and $206 \mathrm{MPa}$, and the main part was completely dissolved and melted at $620^{\circ} \mathrm{C}$ and $301 \mathrm{MPa}$ (Fig. 6), leaving a lot of residue. Some of this residue remained present even at $820^{\circ} \mathrm{C}$ and $486 \mathrm{MPa}$. In the recrystallization experiment of cookeite, the $T_{\mathrm{hDC}}$ in the HDAC chamber was $261^{\circ} \mathrm{C}$ (corresponding to an $\mathrm{H}_{2} \mathrm{O}$ density of $0.78205 \mathrm{~g} \mathrm{~cm}^{-3}$ ). The natural cookeite began obviously dissolving and melting at approximately $500^{\circ} \mathrm{C}$ and $316 \mathrm{MPa}$, leaving residue behind the melting front (Fig. 7). Subse- 

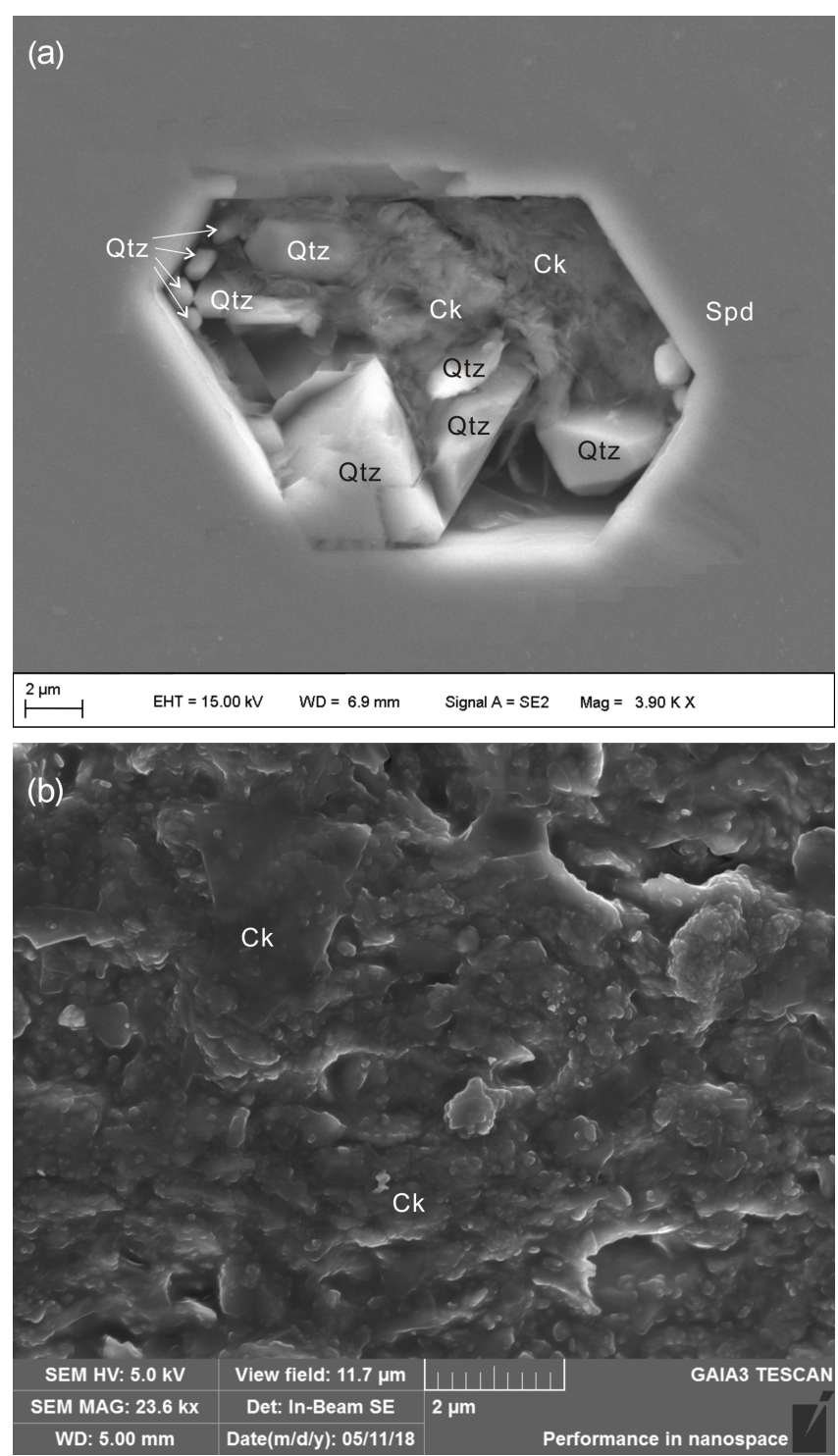

Figure 5. Two SEM images of cookeite crystals in one exposed crystal-rich inclusion hosted in spodumene from the Jiajika pegmatite. The SEM analysis conditions are shown, and the marked lengths are the entire scale bars. $\mathrm{Spd}$ - spodumene; $\mathrm{Ck}$ - cookeite; Qtz - quartz.

quently, cooling was started at $565^{\circ} \mathrm{C}$ and $402 \mathrm{MPa}$, when approximately $40 \mathrm{vol} \%$ of the cookeite had dissolved and melted. During the cooling process, the cookeite recrystallized into fine grains (Fig. 7). After cooling to room temperature $\left(25^{\circ} \mathrm{C}\right)$, a few recrystallized cookeite crystals with high transparency and low fluorescence produced distinct Raman signals with peaks at 98, 167, 219, 266, 342, 382, 457, 592, and $710 \mathrm{~cm}^{-1}$ (Fig. 3c). Note that a peak of recrystallized cookeite near $3640 \mathrm{~cm}^{-1}$, similar to that shown in Fig. 4, was observed.

\section{Discussion}

\subsection{Raman spectra of cookeite within the CIs of the Jiajika pegmatite}

In SEM images, the cookeite-like hydrous solid phase appeared as fine scales or spherulites (Fig. 5), consistent with the shape of cookeite described in Anthony et al. (2001). The hydrous solid phase contained $15.90 \mathrm{wt} \%$ undetermined mass (Table 1); according to the ToF-SIMS analysis (Fig. S1), part of the undetermined mass was lithium, and the Raman spectrum peak at $3640 \mathrm{~cm}^{-1}$ (Fig. 4) inferred an $\mathrm{H}_{2} \mathrm{O}$ content exceeding $10 \mathrm{wt} \%$ in the hydrous solid phase, as estimated using the method of Thomas (2000). The analyzed composition (Table 1) approaches the ideal composition of cookeite (47.96 wt \% $\mathrm{Al}_{2} \mathrm{O}_{3}, 35.51 \mathrm{wt} \% \mathrm{SiO}_{2}, 2.87 \mathrm{wt} \% \mathrm{Li}_{2} \mathrm{O}$, and $13.03 \mathrm{wt} \%$ $\mathrm{H}_{2} \mathrm{O}$ ). Based on the analyzed composition, the chemical formula of the hydrous crystal was calculated as $\mathrm{Li}_{1.005}\left(\mathrm{Al}_{3.997} \mathrm{Fe}_{0.018}\right)\left(\mathrm{Si}_{3.086} \mathrm{Al}_{0.914}\right) \mathrm{O}_{10.076} \mathrm{OH}_{7.902} \mathrm{~F}_{0.098}$, being consistent with ideal empirical formula $\mathrm{LiAl}_{4}\left(\mathrm{Si}_{3} \mathrm{Al}\right) \mathrm{O}_{10}(\mathrm{OH})_{8}$ of cookeite (Anthony et al., 1995). It is purer than cookeite formed as a late hydrothermal alteration product of lithium-bearing minerals in pegmatite. For example, the cookeite from Minas Gerais pegmatite, Brazil, that incorporated $0.62 \mathrm{wt} \% \mathrm{~F}, 0.24 \mathrm{wt} \% \mathrm{MnO}$, 0.09 wt $\% \mathrm{SnO}, 0.08$ wt $\% \mathrm{SrO}, 0.03$ wt $\% \mathrm{Cs}_{2} \mathrm{O}, 0.03$ wt $\%$ $\mathrm{Pb}, \quad 0.02 \mathrm{wt} \% \mathrm{~K}_{2} \mathrm{O}, 0.01 \mathrm{wt} \% \mathrm{Cl}$, and cookeite from the Dolní Bory-Hatě pegmatite in Czechia incorporated with $\mathrm{Fe}\left(\mathrm{Fe}_{\text {tot }} \leq 0.08 \mathrm{apfu}\right), \mathrm{Mg} \quad(\leq 0.07 \mathrm{apfu})$, and $\mathrm{K}$ ( $\leq 0.15 \mathrm{apfu}$ ) (Novák et al., 2015). In contrast, cookeite crystals from the Kalbinsky Range pegmatite and the Djalair pegmatite in Russia bear the chemical formulas of $\left(\mathrm{Li}_{1.11} \mathrm{Na}_{0.02} \mathrm{~K}_{0.01}\right)_{\sum=1: 14}\left(\mathrm{Al}_{3.89} \mathrm{Fe}_{0.05}^{2+} \mathrm{Ca}_{0.04} \mathrm{Mg}_{0.03}\right)_{\sum=4.01}$ $\left(\mathrm{Si}_{2.95} \mathrm{Al}_{1.05}\right)_{\sum=4.00} \mathrm{O}_{10}(\mathrm{OH})_{8}$ and $\mathrm{Li}_{0.7}\left(\mathrm{Al}_{3.96} \mathrm{Fe}_{0.09}^{3+} \mathrm{Fe}_{0.04}^{2+}\right)_{\sum=4.09}\left(\mathrm{Si}_{3.38} \mathrm{Al}^{0.62}\right)_{\sum=4.00} \mathrm{O}_{10.35}$ $(\mathrm{OH})_{7.65}$, respectively (Anthony et al., 1995).

The above analysis and calculations confirm that the CIhosted hydrous crystal in the Jiajika pegmatite is cookeite. Furthermore, because the distinct Raman peaks of this hydrous solid phase were consistent with those of natural cookeite recrystallized in the HDAC chamber (Fig. 3), we conclude that cookeite yields characteristic Raman peaks at $98,167,219,266,342,382,457,592,710$, and $3640 \mathrm{~cm}^{-1}$ (Figs. 3 and 4).

\subsection{Formation mechanism of cookeite with distinct Raman spectra}

The cookeite in the spodumene-hosted CIs in Tanco pegmatite (e.g., Anderson, 2013) usually coexists with quartz and was proposed as forming during or after the incursion of late aqueous fluid along cleaved or fractured spodumene. The expected formation mechanism is an alteration reaction 

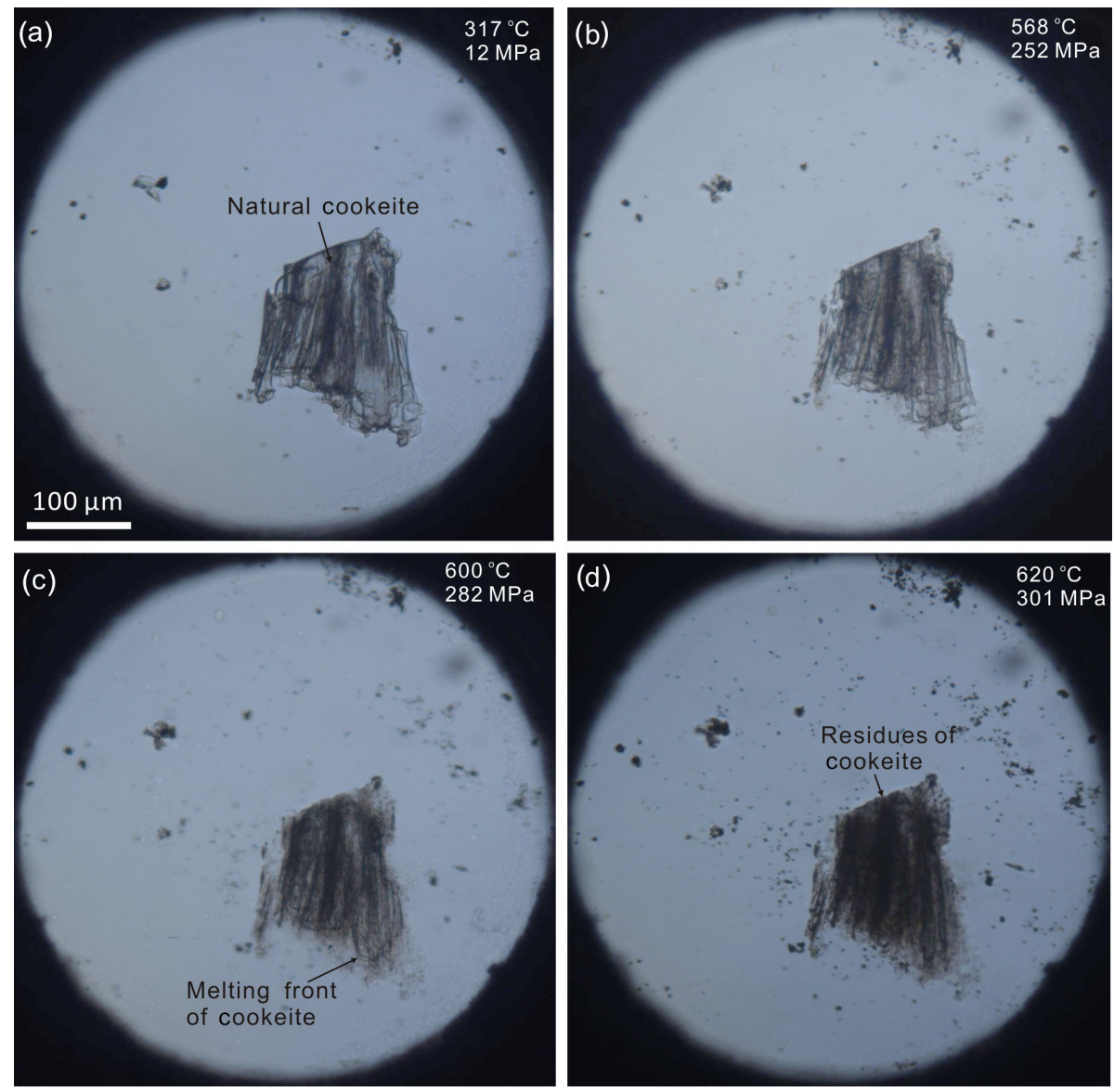

Figure 6. Images of the HDAC sample chamber during the cookeite dissolution and melting experiment: (a) natural cookeite surrounded by pure water at $12 \mathrm{MPa}$ and $317^{\circ} \mathrm{C}$; (b) cookeite dissolving in water at $252 \mathrm{MPa}$ and heated to $568^{\circ} \mathrm{C}$ at $5^{\circ} \mathrm{C} \mathrm{min}{ }^{-1}$; (c) cookeite dissolving and melting at $282 \mathrm{MPa}$ and $600^{\circ} \mathrm{C}$ (heated at $1^{\circ} \mathrm{C} \mathrm{min}{ }^{-1}$ ), showing the cookeite melting front; and (d) cookeite residue after dissolution of the main part in water at $301 \mathrm{MPa}$ and $620^{\circ} \mathrm{C}$ (heated at $1^{\circ} \mathrm{C} \mathrm{min}^{-1}$ ). This residue remained even at $486 \mathrm{MPa}$ and $820^{\circ} \mathrm{C}$. Pressures were calculated for a bulk $\mathrm{H}_{2} \mathrm{O}$ density of $0.67681 \mathrm{~g} \mathrm{~cm}^{-3}$.

of spodumene $+\mathrm{H}_{2} \mathrm{O} \rightarrow$ cookeite + quartz (Anderson et al., 2001; Anderson and Maccarron, 2011).

However, many features of the CIs in the Jiajika pegmatite indicate these CIs to be primary in origin without incursion of late fluid (Li and Chou, 2016, 2017). The CIs in the Jiajika pegmatite usually have a crystal shape of spodumene (e.g., the $\mathrm{CI}$ in Fig. 5a), indicating the CIs were trapped during spodumene growth. And, in the CI with a perfect shape of spodumene shown in Fig. 5a, cookeite and bipyramidal quartz are strictly confined within the CI, implying that cookeite and quartz crystallized from the entrapped fluid in the CI. Furthermore, within the CIs in the Jiajika deposit, $\mathrm{SiO}_{2}$ is more frequently crystallized as cristobalite (Figs. 1 and 2), showing different mineral assemblages to the above alteration reaction of spodumene. We consider that when zabuyelite or calcite crystallized at about $500-600^{\circ} \mathrm{C}$ in the closed space of the CIs (Ding et al., 2016), the rapid pressure decrease in the CIs induced cristobalite rather than quartz crystallization in the $400-600^{\circ} \mathrm{C}$ range ( $\mathrm{Li}$ and Chou, 2016). These features indicate the CIs in the Jiajika pegmatite were primary in origin and were trapped during spodumene crystallization, excluding cookeite formation through an alteration reaction of spodumene during the incursion of late fluid along cleaved or fractured spodumene, as suggested by Anderson and Maccarron (2011). Additionally, the clean and straight contact face between cookeite and its spodumene host excludes cookeite formation through an alteration reaction between the trapped aqueous fluid and spodumene (the hosting mineral) (Figs. 2, 5). In the CI homogenization experiments, the cookeite with cristobalite melted in the 400 $600{ }^{\circ} \mathrm{C}$ range, consistent with the cookeite stability field reported by Vidal and Goffé (1991) and with the temperature range of pegmatite crystallization (London, 2008). Therefore, cookeite might directly crystallize at relatively high $P$ $T$ conditions from the fluid entrapped in the closed space of CIs. The cookeite crystallization process in the closed space of CIs would consume the $\mathrm{H}_{2} \mathrm{O}$ within the CIs, leaving a small amount of aqueous fluid or no aqueous fluid at all co- 

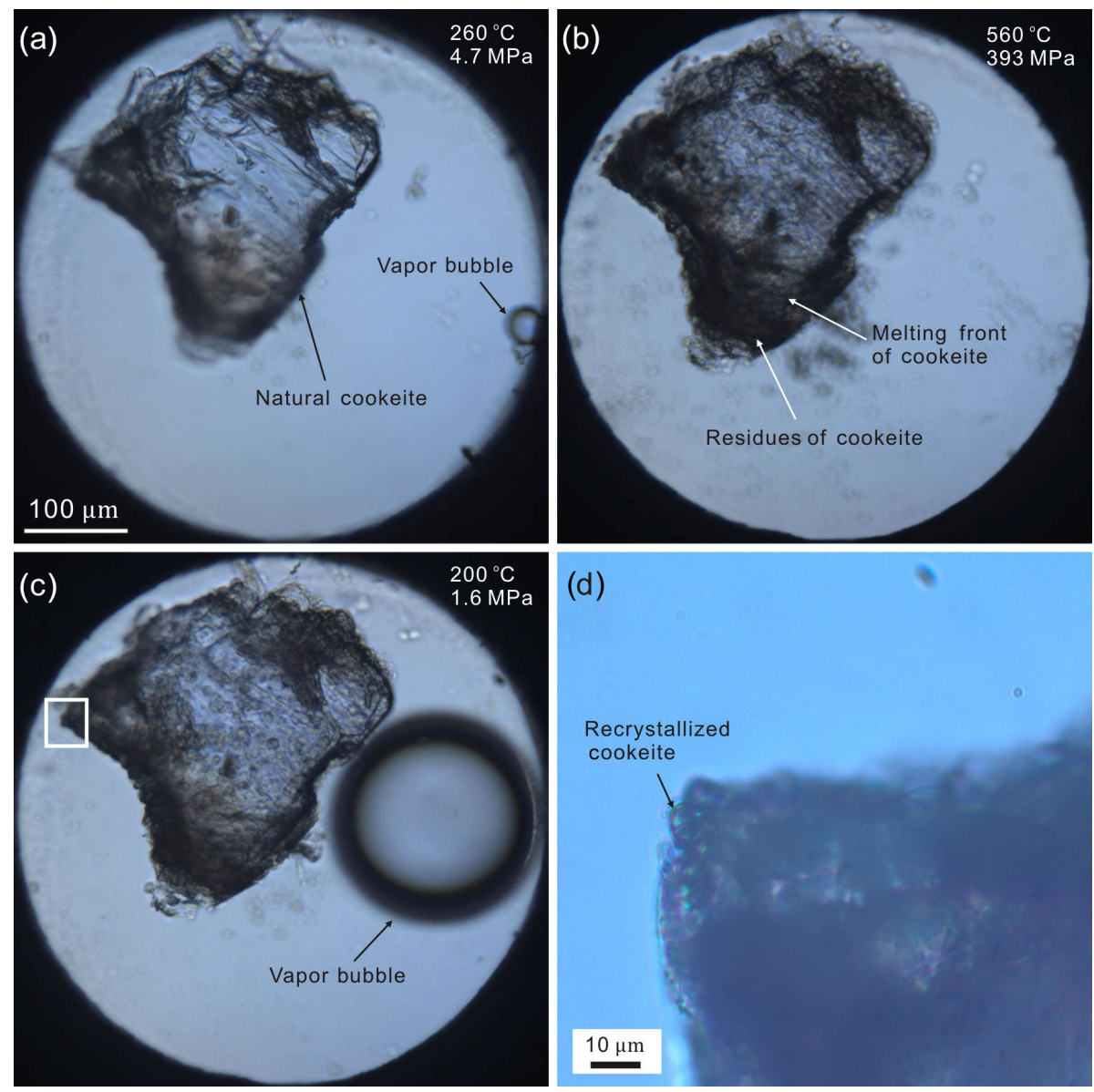

Figure 7. Images of the HDAC sample chamber during the cookeite recrystallization experiment: (a) natural cookeite surrounded by pure $\mathrm{H}_{2} \mathrm{O}$ at $260^{\circ} \mathrm{C}$ and $4.7 \mathrm{MPa}$ (bulk $\mathrm{H}_{2} \mathrm{O}$ density $=0.78205 \mathrm{~g} \mathrm{~cm}^{-3}$; vapor bubble disappears at $261^{\circ} \mathrm{C}$ ); (b) cookeite dissolving in water at $560^{\circ} \mathrm{C}$ and $393 \mathrm{MPa}(\sim 40 \%$ cookeite (by volume) has melted, leaving residue behind the melting front); (c) the recrystallized cookeite at $200^{\circ} \mathrm{C}$ and 1.6 $\mathrm{MPa}$ (vapor bubble appears during cooling); and (d) recrystallized cookeite (enlargement of the area enclosed in the rectangle in $\mathbf{c}$ is highly transparent and provides distinct Raman signals; see Fig. 3c).

existing with the cookeite, as shown in Figs. 1 and 2. It could also be the reason that the shapes of cookeite showing scales or spherulites within CIs in the Jiajika pegmatite were different from shapes of secondary cookeite as foliations or sheets described by Anderson and Mccarron (2011) and Novák et al. (2015).

In contrast to the CI-hosted cookeite in the Jiajika pegmatite, the cookeite formed in a relatively open system through the alteration reaction. It could cause cookeite to be highly inhomogeneous (Gunter, 2018), as the loose crystal lattice of cookeite easily absorbs many components, such as $\mathrm{Na}, \mathrm{Ca}, \mathrm{Mg}, \mathrm{K}, \mathrm{Fe}, \mathrm{P}$, and F (Černý, 1970). For example, the natural cookeite sample from Minas Gerais pegmatite, Brazil, contained $0.62 \mathrm{wt} \% \mathrm{~F}, 0.24 \mathrm{wt} \% \mathrm{MnO}$, 0.09 wt $\% \mathrm{SnO}, 0.08$ wt $\% \mathrm{SrO}, 0.03 \mathrm{wt} \% \mathrm{Cs}_{2} \mathrm{O}, 0.03 \mathrm{wt} \%$ $\mathrm{Pb}, 0.02$ wt $\% \mathrm{~K}_{2} \mathrm{O}$, and $0.01 \mathrm{wt} \% \mathrm{Cl}$. As a result, residue of natural cookeite remained in the HDAC during the melting and recrystallization experiments (see Figs. 6 and 7). Correspondingly, the secondary cookeite with high impu- rities usually produce Raman spectrum with high fluorescence, as shown Fig. 3d and in the RRUFF Raman database (Downs, 2006); as a result, no distinct Raman spectrum of cookeite were ever reported (Anderson and Mccarron, 2011). On the other hand, the cookeite with low fluorescence crystallized in the closed space of CIs in the Jiajika pegmatite is purer than the secondary cookeite, as shown in Table 1. The high purities are also proven by the phenomenon that no residue were observed after total melting of cookeite and other daughter minerals in the CIs of spodumene from the Jiajika pegmatite in the total homogenization experiments conducted by Li and Chou (2017). Furthermore, the natural cookeite recrystallized in the sealed HDAC sample chamber yielded distinct Raman signals, which resembled those collected from the hydrous solid phase of spodumene-hosting CIs in Jiajika pegmatite. Therefore, the purities of cookeite crystallized at relatively high $P-T$ conditions in a closed space (e.g., CIs) could be the reason of cookeite exhibiting low fluorescence. Therefore, if a cookeite sample ex- 
hibits distinct Raman signals, it probably formed in a closed space at relatively high $P-T$ conditions. It indicates that the cookeite-bearing CIs in the spodumene from the Jiajika lithium pegmatite deposit are primary inclusions containing trapped a pegmatite-crystallization medium, such as boundary-layer liquid (London, 2018) or hydrous-silicate (Btype) melt (Thomas and Davidson, 2016). This conjecture supports our previous study, in which we inferred a primary nature of these CIs from the presence of cristobalite within them (Li and Chou, 2016).

\section{Conclusions}

In this paper, we reported a type of cookeite hosted in CIs in the spodumene of the Jiajika pegmatite, which yields distinct Raman peaks at 98, 167, 219, 266, 342, 382, 457, 592, 710, and $3640 \mathrm{~cm}^{-1}$. Raman spectroscopy has many advantages, it is non-osculatory and nondestructive and has a high sensitivity, short examination time, small sample size, and nonpreparative sample (Chou and Wang, 2017). Therefore, our reported Raman spectrum of cookeite makes it possible to use this advantageous tool for identifying cookeite that likely formed in enclosed spaces (i.e., which yields distinct Raman signals).

Crystallization within the closed space at relatively high $P-T$ conditions might explain the high purity and distinct Raman signals of the cookeite derived from the Jiajika pegmatite. As a result, this type of cookeite is unusual and provides an indicator of cookeite crystallized in the closed space of a primary inclusion (e.g., CI). By recognizing the primary nature of the CIs in the spodumene from the Jiajika pegmatite, we can better understand and describe the formation mechanisms of CIs and pegmatites.

Data availability. All essential data were presented in Sect. 4 "Analytical results" and Table 1 .

Supplement. The supplement related to this article is available online at: https://doi.org/10.5194/ejm-32-67-2020-supplement.

Author contributions. XD analyzed the cookeite samples by using a Raman spectrometer, an EMP, an FIB-SEM, and a ToF-SIMS and also wrote the paper. JL provided the idea of how to identify the Raman spectrum of cookeite and explain the formation mechanism of cookeite with distinct Raman spectra in crystal-rich inclusions. IMC proposed the significance of cookeite with distinct Raman spectra and gave advice that improved the paper. ZC calculated the IMA formula of cookeite according to the EMPA results. SL gave assistance in EMP analysis.
Competing interests. The authors declare that they have no conflict of interest.

Acknowledgements. We would like to thank two anonymous reviewers for their constructive reviews. The National Museum of Natural History of the Smithsonian Institution supplied the natural cookeite sample from Minas Gerais pegmatite, Brazil. Raman analyses were performed at Horiba (China) Trading Co., Ltd., Beijing Branch.

Financial support. This research has been supported by the National Key Research and Development Program (2019YFC0605203), the National Natural Science Foundation of China (grant no. 41872096), the Chinese National Non-profit Institute Research Grant of CAGS (grant no. JYYWF201814), the Knowledge Innovation Program (grant no. SIDSSE-201302), the Hadal-trench Research Program (grant no. XDB06060100), and the Key Frontier Science Program, Chinese Academy of Sciences (grant no. QYZDY-SSW-DQC008).

Review statement. This paper was edited by Sergey Krivovichev.

\section{References}

Anderson, A. J.: Are silicate-rich inclusions in spodumene crystallized aliquots of boundary layer melt?, Geofluids, 13, 460-466, 2013.

Anderson, A. J. and Maccarron, T.: Three-dimensional textural and chemical characterization of polyphase inclusions in spodumene using a dual focused ion beam-scanning electron microscope (FIB-SEM), Can. Mineral., 49, 541-553, 2011.

Anderson, A. J., Clark, A. H., and Gray, S.: The occurrence and origin of zabuyelite $\left(\mathrm{Li}_{2} \mathrm{CO}_{3}\right)$ in spodumene hosted fluid inclusions: implications for the internal evolution of rare-element granitic pegmatites, Can. Mineral., 39, 1513-1527, 2001.

Anthony, J. W., Bideaux, R. A., Bladh, K. W., and Nichols, M. C.: Handbook of Mineralogy, Mineral Data Publishing, Tucson Arizona, USA, The Mineralogical Society of America, II, p. 159, 1995.

Bobos, I., Vieillard, P., Charoy, B., and Noronha, F.: Alteration of spodumene to cookeite and its pressure and temperature stability conditions in Li-bearing aplite-pegmatites from northern Portugal, Clay Clay Miner., 55, 295-310, 2007.

Černý, P.: Compositional variation in cookeite, Can. Mineral., 10, 636-647, 1970.

Chou, I-M. and Wang, A.: Application of laser Raman microanalyses to Earth and planetary materials, J. Asian Earth Sci., 145, 309-333, 2017.

Ding, X., Li, J., Li, S., and Wang, X.: Crystallization experiment study of zabuyelite using hydrothermal diamond-anvil cell, Acta Geol. Sin., 90, 873-878, 2016 (in Chinese with English abstract).

Downs, R. T.: The RRUFF project: an integrated study of the chemistry, crystallography, Raman and infrared spectroscopy of minerals, (abs.) the 19th General Meeting of the International Mineralogical Association, O03-13, 2006. 
Gunter, R.: Tanco Mine Hydrothermal Secondary Minerals (Online), available at: https://www.mindat.org/article.php/2748/ Tanco+Mine+Hydrothermal+Secondary+Minerals+, last access: March 2018.

Heinrich, E. W.: Economic geology and mineralogy of petalite and spodumene pegmatites, Ind. J. Earth Sci., 2, 18-29, 1975.

Li, J. and Chou, I-M.: An occurrence of metastable cristobalite in spodumene-hosted crystal-rich inclusions from Jiajika pegmatite deposit, China, J. Geochem. Explor., 171, 29-36, 2016.

Li, J. and Chou, I-M.: Homogenization experiments of crystalrich inclusions in spodumene from Jiajika lithium deposit, China, under elevated external pressures in a hydrothermal diamond-anvil cell, Geofluids, 2017 9252913, https://doi.org/10.1155/2017/9252913, 2017.

Li, J., Wang, D., Zhang, D., and Fu, X.: Mineralizing mechanism and continental geodynamics of typical pegmatite deposits in western Sichuan, China, Atomic Energy Press, Beijing, 187 pp., 2007 (in Chinese with English abstract).

Li, J., Chen, Y., and Wang, D.: The ore-forming mechanism of the Jiajika pegmatite type rare metal deposit in western Sichuan province: evidence from isotope dating, Acta Geol. Sin.-Engl., 87, 91-101, 2013a.

Li, J., Chou, I-M., Yuan, S., and Burruss, R. C.: Observations on the crystallization of spodumene from aqueous solutions in a hydrothermal diamond-anvil cell, Geofluids, 13, 467-474, $2013 \mathrm{~b}$.

Li, J., Bassett, W. A., Chou, I. M., Ding, X., Li, S. H., and Wang, X. Y.: An improved hydrothermal diamond anvil cell, Rev. Sci. Instrum., 87, 1513-1527, 2016.

London, D.: The magmatic-hydrothermal transition in the Tanco rare-element pegmatite: evidence from fluid inclusions and phase equilibrium experiments, Am. Mineral., 71, 376-395, 1986.

London, D.: Melt boundary layers and the growth of pegmatitic textures (abstr.), Can. Mineral., 37, 826-827, 1999.

London, D.: Pegmatites, Can. Mineral., Special Publication 10, Québec, 347 pp., 2008.

London, D.: Ore-forming processes within granitic pegmatites, Ore Geol. Rev., 101, 349-383, 2018.

London, D. and Burt, D. M.: Alteration of spodumene, montebrasite, and lithiophilite in pegmatites of the White Picacho district, Arizona, Am. Mineral., 67, 97-113, 1982.
Novák, M., Čopjaková, R., Dosbaba, M., Galiová, M. V., Všianský, D., and Staněk, J.: Two paragenetic types of cookeite from the Dolní Bory-Hatě Pegmatites, Moldanubian Zone, Czech Republic: Proximal and distal alteration productions of Li-bearing sekaninaite, Can. Mineral., 53, 1035-1048, 2015.

Roedder, E.: Fluid inclusion evidence for immiscibility in magmatic differentiation, Geochim. Cosmochim. Ac., 56, 5-20, 1992.

Thomas, R.: Determination of water contents of granite melt inclusions by confocal laser Raman microprobe spectroscopy, Am. Mineral., 85, 868-872, 2000.

Thomas, R. and Davidson, P.: Revisiting complete miscibility between silicate melts and hydrous fluids, and the extreme enrichment of some elements in the supercritical state - Consequences for the formation of pegmatites and ore deposits, Ore Geol. Rev., 72, 1088-1101, 2016.

Thomas, R., Webster, J. D., and Heinrich, W.: Melt inclusions in pegmatite quartz: Complete miscibility between silicate melts and hydrous fluids at low pressure, Geochim. Cosmochim. Ac., 139, 394-401, 2000.

Thomas, R., Davidson, P., and Badanina, E.: A melt and fluid inclusion assemblage in beryl from pegmatite in the Orlovka amazonite granite, East Transbaikalia, Russia: Implications for pegmatite-forming melt systems, Mineral. Petrol., 96, 129-140, 2009.

Thomas, R., Davidson, P., and Beurlen, H.: Tantalite-(Mn) from the Borborema Pegmatite Province, northeastern Brazil: Conditions of formation and melt- and fluid-inclusion constraints on experimental studies, Mineral. Petrol., 46, 749-759, 2011a.

Thomas, R., Webster, J. D., and Davidson, P.: Be-daughter minerals in fluid and melt inclusions: Implications for the enrichment of Be in granite-pegmatite systems, Contrib. Mineral. Petrol., 161, 483-495, 2011b.

Vidal, O. and Goffé, B.: Cookeite $\mathrm{LiAl}_{4}\left(\mathrm{Si}_{3} \mathrm{Al}\right) \mathrm{O}_{10}(\mathrm{OH})_{8}$ : Experimental study and thermodynamical analysis of its compatibility relations in the $\mathrm{Li}_{2} \mathrm{O}-\mathrm{Al}_{2} \mathrm{O}_{3}-\mathrm{SiO}_{2}-\mathrm{H}_{2} \mathrm{O}$ system, Contrib. Mineral. Petrol., 108, 72-81, 1991.

Wagner, W. and Pruss, A.: The IAPWS formulation 1995 for the thermodynamic properties of ordinary water substance for general and scientific use, J. Phys. Chem. Ref. Data, 31, 387-535, 2002. 